\title{
Linguistics of saying, presentation
}

\author{
Jesús Martínez del Castillo \\ Department of Philology, Faculty of Business Studies and Tourism, Universidad de Almería, Almería, Spain
}

Email address:

jesus.gerardo@ual.es, apofansis@msn.com

\section{To cite this article:}

Jesús Martínez del Castillo. Linguistics of Saying, Presentation. International Journal of Language and Linguistics. Special Issue: Linguistics of Saying. Vol. 3, No. 6-1, 2015, pp. 1-4. doi: 10.11648/j.ijll.s.2015030601.11

\begin{abstract}
Linguistics of Saying is a theory about language based on a particular conception of what to be a human being is. Human subjects are free and historical. The aim of linguistics of saying is thought and its means is the analysis of speech acts conceived of as acts of knowing. In this sense linguistics of saying is hermeneutics, both transcendental and empirical. As Humboldt would say, it is transcendental hermeneutics and empirical verification.
\end{abstract}

Keywords: Human Beings, Human Subjects, Speaking, Saying and Knowing, Thought

\section{Introduction}

Linguistics of Saying is a theory about language based on a particular conception of what to be a human being is. A human being is a human subject who is in a particular circumstance and must do something in order to survive ${ }^{1}$. The circumstances human subjects are thrown into, are various and heterogeneous thus making their living in this world uncertain and determinable. Since their way of being is determinable but not determined, human subjects must decide what to do in the most immediate future. Human life thus is made up of a series of decisions trying to overcome the circumstance they are in. The most immediate circumstance human subjects meet when they are thrown into this world is, constituted by the members of the speech community they belong to. A baby just born will cry when it feels uncomfortable in some way. With this, it will understand that the only means for its defense is in the bonds it has and can establish with the other members of the society it is thrown into. Because of this it will soon identify itself with the group, especially with its mother. In a short period of time, it will discover that the grown-ups utter sounds to establish a connection with it thus encouraging and prompting it to answer accordingly. He will soon imitate them trying to utter the sounds it hears from its grown-ups.

\footnotetext{
${ }^{1}$ Ortega y Gasset 1994, p. 190.
}

\section{Dimensions in Human Subjects}

With this, from the very start, human subjects manifest themselves with a double dimension, the dimension subject-object and the dimension subject-subject. Because of the first dimension the human subject creates things and arranges them in a world made up of things, because he must make up his mind in the circumstance he is in. And because of the second one, the human subject manifests his peculiar way of being, a subject who is together-with-another-one, together with the listener. Because of the first dimension, the human subject is creative, that is, free, absolute, transcendent, that is, a subject going beyond the forms and means for living he uses; or in other words: a human subject will always aim at achieving something different from his actions, that is, human actions are purposeful. Because of the second one, he is limited and contingent, thus participating with others in the same level of historicity. A human subject is nothing made beforehand. He must make himself in history, making up his mind in the circumstance he is in. Because of this, he is historical, that is, a subject made in history.

\section{Language, the Manifestation of Human Intelligence and Freedom}

Language as the exclusive and defining specific propriety of humans, must answer to the specific nature of humans. Language is nothing but the manifestation of human intelligence and freedom. Language thus is

1 Creative, that is, absolute, transcendent, because human 
subjects are free and absolute.

2 Meaningful because it goes beyond words and expressions. Meaning is nothing but contents of conscience.

3 It is for others, thus aiming at the listener, because a human subject is together-with-another-one, together with his listeners.

4 Historical and thus common and social because all speakers participate in the activity of speaking. In this sense, language will change in the particular languages it is constituted in because human subjects live in a particular period of time in history.

5 Material, that is, made in sounds, objectified meanings and attitudes, because human conscience manifests itself in objectified things.

Language thus cannot be explained unless it is referred to humans and the human nature.

\section{Language and Thought (Lógos)}

Since language is transcendent and meaningful, language is both speaking and understanding. Since understanding involves interpreting. Language is thought, that is lógos. Lógos is nothing but the state lived by the individual speaker at the moment of speaking manifesting itself because of speaking. But lógos is being created in terms of the words and expressions uttered at the moment of speaking. In this sense, it is necessary to establish a double distinction in logos:

a) Lógos semantikós, that is inter-subjective and common lógos, something previous to words and expressions really uttered. It is the state lived the speaker in so far as it is common, not yet determined with the concepts of truth/non-truth and existence/non-existence; and

b) Lógos apophantikós, the lógos determined with the concepts of truth/non-truth and existence/non-existence.

\section{Language as a Mental Activity}

Since understanding involves thought, the activity of speaking is a complex one. Human subjects intuit, create, acquire, perform, speak and say, interpret, use, evaluate and, even, speak of language. Language thus is a mental activity involving different sets of other mental activities. Human subjects speak because they have something to say; they say because they define themselves in the circumstance they are in at any moment; and they speak and say because they are able to know. Language thus is something coming from the inside of the human subjects. On the contrary, a language is something coming to the speaker from the outside, from the speech community. And the speech act is nothing but the expression of the meaningful purpose of the individual speaker. Language, thus, is the activity of speaking, saying and knowing.

\section{Levels in the Activity of Speaking}

Since language is activity, you can see three levels in it to be applied both to language and thought. Language is universal, that is, something defining all human subjects. It is historical, that is, something made in history with the participation of all speakers in a linguistic community. And language is individual, the performance of language and a particular language in speech.

\section{Levels in Lógos}

The same applies to lógos. Lógos semantikós is universal since it is the meaningful function; it is historical in so far as the meaningful function is determined in the elements of a language; and it is individual since it manifests itself in texts.

Logos apophantikós is universal since the logic manifests itself as different from the linguistic, it is knowledge, and objective classifications of reality do not belong to language: objective classifications are not lexical systematizations. It is historical since reality and knowledge of reality impose on intuition and meaning. And it is individual since it appears in those particular texts in which reality is described.

\section{Levels in Linguistic Content}

And the same applies to linguistic content. In any expression you can see the three levels of linguistic determination, namely: designation or the connection of words to things in the world; meaning, or the particular systematization of human experience in a particular language; and sense, the use of designation and meaning to express a particular thing by a particular speaker in a particular context.

\section{The Intentional Meaningful Purpose of the Individual Speaker}

Because of this, language is to be described in its birth. Language is born whenever it is spoken, Linguistics of saying aims at describing the intentional meaningful purpose of the individual speaker. It starts from the speech act and tries to determine the degree of reality of the thing we call language. The speech act, the only thing with concrete existence, is to be analyzed as an act of knowing.

\section{The Speech Act as an Act of Knowing}

Since language is the activity of speaking, saying and knowing, the speech act is the result of an act of knowing. In the act of knowing, the human subject,

a) Separates himself from the sensitive and concrete, that is to say, from the sensation coming to him through his senses.

b) Transforms what comes through his senses, something sensitive and concrete, into abstract and virtual.

c) Thus performing some intellective operations in his inside, that is, in his conscience.

d) In order to overcome the circumstance the subject is in.

e) Thus creating something not existing before, something 
new.

These actions are nothing but manifestations of human intelligence and freedom. Because of these the human subject creates

1. His own I or conscience.

2. Virtual things, that is, contents of his conscience, meanings, objectified in words, that is, language.

3. Things and a world full of things, that is, reality.

4. A particular language, because the human subject uses words not belonging to him but the speech community he lives in.

\section{Language and Modes of Thinking}

Since human subjects live language, and since they will speak a particular language — whenever you speak you will speak a particular language-, they themselves will identify with the techniques of expression in their particular language. The particular language and the techniques of expression in it are historical systems of speaking, something contingent thus constituting traditions in the technique of speaking. The techniques of expression of a particular language bear with them a particular conception of the world. This is to be called a mode of thinking, that is, a system of beliefs in force in a particular language.

Due to the beliefs transmitted by the western languages the way of conceiving of things in the western world is peculiar of this civilization, different from others. This fact goes beyond language use but it is the support of the conception of things reflected in language use. It constitutes the mode of being of things. In the Western World the way of conceiving of things is the so-called Substantive Being. The mere fact of referring to language, for example, with a noun makes us conceive of the reality of it as something existing in itself, something objective, something there, something really existing, independent from anything else, and considering it as if it was an entity.

\section{Linguistics of Saying and the Mode of Thinking of Speakers}

Since human subjects are influenced with the ideas and beliefs in force in their speech community when conceiving of things, linguistics of saying aims, as well, at determining the mode of thinking of speakers.

\section{Linguistics of Saying as Hermeneutics}

Since language is something having to do with humans and the human reality, linguistics of saying cannot be but hermeneutics, that is, interpretation, both transcendental and synthetic, that is, a priori and experimental: interpretation of facts both in terms of reason and in terms of the things they are connected with.

Linguistics of saying is transcendental because it goes beyond the things said and the activities performed. It is experimental since its statements constitute syntheses of intellect (reason) and sensibility (experience) by means of imagination. Because of this, its statements are synthetic $a$ priori.

\section{About this Special Issue}

This Special Issue of the International Journal of Language and Linguistics will deal with Linguistics of Saying but not exclusively since there some other theories studying the problem involved, namely, posing the fundamental problem of language and thought. This problem is usually called cognition and studied in the so-called Cognitive Linguistics. Apart from this, there are many linguists who, from different positions in the study of language, analyze the problem of language and thought.

A branch of language studies very similar to Linguistics of Saying is the so-called Text Linguistics, a discipline proposed by Coseriu and sometimes today developed with different principles with the name of Discourse Analysis. This branch of knowledge is hermeneutics as well.

\section{Parts in this Special Edition}

This special issue will have two parts. Part one will deal with Linguistics of Saying, and part two with the analysis of thought, either if the article follows the principles of Linguistics of Saying or not.

\section{References}

[1] Coseriu, Eugenio, Principios de semántica estructural. Madrid: Gredos, 1981 (1977).

[2] Coseriu, E. Introducción a la lingüística, Madrid: Gredos, 1986 [1951].

[3] Coseriu, E., Sincronía, diacronía e historia: el problema del cambio lingüístico, Madrid, Editorial Gredos, 1988 [1957].

[4] Coseriu, E., Competencia lingüística: elementos de la teoría del hablar, Madrid, Editorial Gredos, 1992 [1988].

[5] Coseriu, E. y Ó. Loureda: Lenguaje y discurso, Pamplona, Eunsa, 2006.

[6] Coseriu, E. Lingüística del texto. Introducción a la hermenéutica del sentido, Arco/Libros, 2007.

[7] Di Cesare, D. Wilhelm von Humboldt y el estudio filosófico de las lenguas, traducción de Ana Agud, Anthropos, 1999.

[8] Heidegger, Martín, Carta sobre el humanismo, Madrid: Destino, 1970 .

[9] Humboldt, Wilhelm von, Sobre la diversidad de la estructura del lenguaje humano y su influencia sobre el desarrollo espiritual de la humanidad. Traducción de Ana Agud. Madrid: Anthropos y Ministerio de Educación y Ciencia, 1990 (1836).

[10] Kant, Immanuel, Crítica de la razón pura, RBA, 2004.

[11] Martínez del Castillo, Jesús, La lingüística del decir. El logos semántico y el logos apofántico, Granada: Granada Lingvistica,

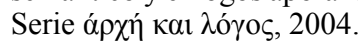


[12] Martínez del Castillo, Jesús, «Hablar, decir y conocer: el acto lingüístico», Oralia, 11 (2008): 375-97.

[13] Martínez del Castillo, Jesús, La lingüística cognitiva: análisis y revisión, Madrid: Biblioteca Nueva, S. A, 2008.

[14] Martínez del Castillo, Jesús: «El logos semántico y el logos apofántico» Enérgeia I, Online-Zeitschrift für Sprachwissenchaft, Sprachphilosophie und Sprachwissenschaftsgeschichte. 2009: 50-80.

[15] Martínez del Castillo, Jesús: Las relaciones lenguaje-pensamiento o el problema del logos. Madrid: Bilbioteca Nueva, 2010.

[16] Martínez del Castillo, Jesús, Sobre las categorias, Buenos Aires, Deauno.com, 2011.

[17] Martínez del Castillo, Jesús, ed. Eugenio Coseriu (1921-2002) en los comienzos del siglo XXI, 2 vols. in Analecta Malacitana, Anejos/86, 2012.

[18] Martínez del Castillo, Jesús: Psicología, lenguaje y libertad, in Analecta Malacitana, Anejos/89, Universidad de Málaga, 2012.
[19] Martínez del Castillo, Jesús: Modes of Thinking, Language and Linguistics, in Analecta Malacitana, Anejos/94, 2013, Universidad de Málaga.

[20] Ortega y Gasset, José, «El decir de la gente: la lengua. Hacia una nueva lingüística» in El hombre y la gente, 2001 [1957], Alianza Editorial.

[21] Ortega y Gasset, José, «El decir de la gente: las "opiniones públicas", las "vigencias sociales". El poder público» in El hombre y la gente, 2001 [1957], Alianza Editorial.

[22] Ortega y Gasset, José, "En torno al coloquio de Darmstadt", published in Meditación de la técnica y otros ensayos de ciencia y filosofia, 2002 [1982]: 192-233.

[23] Ortega y Gasset, José, "Apuntes para un comentario al banquete de Platón“, Obras completas, IX, Taurus, 2009: 729-758.

[24] Ortega y Gasset, José, La idea de principio en Leibniz, Alianza Editorial, 1992a [1958].

[25] Ortega y Gasset, José, ¿Qué es conocimiento?, Alianza Editorial, 1992b [1984]. 